\title{
Effect of Maternal Cytoplasmic on Agronomic Characters of the Result of Crossing Black $\times$ White Rice
}

\author{
Siti Nurhidayah ${ }^{1 *}$, Efrin Firmansyah ${ }^{1}$, Totok Agung D Haryanto ${ }^{2}$, Prita Sari Dewi ${ }^{2}$ \\ ${ }^{I}$ Departement of Agrotechnology, Faculty of Agriculture, Perjuangan University of Tasikmalaya, \\ Tasikmalaya, West Java, 46115, Indonesia \\ ${ }^{2}$ Faculty of Agriculture, Universitas Jenderal Soedirman, Purwokerto Central Java 53123, Indonesia \\ *Corresponding author. Email: nurhidayah.unper@gmail.com
}

\begin{abstract}
The quality of rice is one of the performances preferred by consumers in choosing rice. Determination of female parents is important in assembling rice with the desired quality. This study aims to determine the effect of maternal cytoplasmic on the agronomic characters of crossbreeding black $\times$ white rice. The research was carried out from February to June 2020 at screenhouse of the Faculty of Agriculture, Perjuangan University of Tasikmalaya at an altitude of 350 masl. The plant materials used in the study were the F1 generations and their reciprocals derived from several crossings of Padi Hitam/ $\mathrm{PH}$ (black rice) cultivars and several commercial rice varieties of Inpari. The crossings were made to combine good excellent characters from both parents. The material used was the F1 generation rice seeds from crossing of black $\times$ white rice as many as 15 cross combinations and the reciprocal so that there were 30 cross combinations in total. The seeds were planted in $18 \mathrm{~L}$ buckets at the age of 14 das. Each bucket was planted with 1 seed per hole with a total of 2 seeds per bucket. Data were analysed using paired t-test at an error level of $\alpha=5 \%$. The results showed that there was an effect of maternal cytoplasmic in several cross combinations for six agronomic characters. According to the result of maternal effects on 1000 grain weight and grain yield, PH3, PH4, and PH5 cultivars are recommended to be used as the male parents to improve the performance of the filial generations.
\end{abstract}

Keywords: black rice, cytoplasmic, effect maternal, reciprocal

\section{INTRODUCTION}

The total population of Indonesia is around 268 million with a growth rate of $1.31 \%$ in 2020 (Central Bureau of Statistics/Badan Pusat Statistik (BPS) [1]. The increase in population results in an increase in food consumption which is a vital need for humans. Based on BPS [2], one type of food commodity that is needed by the Indonesian people is rice. According to Rafii et al. [3], over $95 \%$ of the world's rice crop is used for human food, especially for Indonesians that rice is the main food source. BPS [2] states that the population preference for rice is so great, even people who have a non-rice staple food pattern switch to rice because rice is considered the main source of calories and protein.

According to BPS [2], the national rice consumption in 2017 is around 29 million tons with the national rice production averages 54 million tons. From these data, there is excess production. On the other hand, BPS [5] states that the Indonesia government also imports 444 thousand tons of rice for certain types of rice, one of which is functional rice. Food problems apart from the need for rice continue to increase due to population size and health preferences as well as various challenges. Another problem is the conversion of paddy fields to settlements, industry, road infrastructure [6], and the issue of global warming. Therefore, plant breeding plays an important role in assembling new varieties to meet national food.

One method of plant breeding is to do artificial hybridization by crossing distinct parents so that the offspring can be obtained as expected. The cytoplasm is carried by the female parent while the male parent carries only the nucleus. According to Liu et al. [7], cytoplasmic effects have been known to have various effects on the agronomic properties of plants and help accelerate breeding programs. Cytoplasmic effect has a significant negative effect on the length of rice kernels before cooking [8]. Maternal effects have a significant positive effect on the number of bollards [9]. and there is a significant difference between F1 and F1R in durum wheat (Triticum durum) [10]. In addition, according to Qin et al. [11], maternal effects have a positive effect on yield, number of seeds, grain weight per panicle of rice plants. Several crossings have been made between local black rice cultivars in Tasikmalaya called as Padi Hitam/PH (black 
rice/Oryza sativa) and commercial rice varieties (Inpari 13, Inpari 18, and Inpari 19). The purpose of the hybridization is to combine good character from both parents. Inpari varieties known to have excellent productivity, early maturity, and resistance to brown planthopper and bacterial leaf blight. On the other side, black rice cultivars show high content of anthocyanin, high dietary fiber, and low glycemic index. This study aims to examine the effect of female parents on the agronomic characters of rice plants.

\section{MATERIALS AND METHODS}

The research was conducted from February to July 2020 at the screenhouse of Faculty of Agriculture, Perjuangan University of Tasikmalaya at an altitude of 350 masl. The research materials used were 30 genotypes consisting of $15 \mathrm{~F} 1$ genotypes and $15 \mathrm{~F} 1 \mathrm{R}$ genotypes. The seedlings were planted 14 days after the seedlings were planted in $18 \mathrm{l}$ buckets. Each genotype was planted as many as 12 plants and 4 plants reciprocally. The media used were soil and compost with a ratio of 1:1. Plants are fertilized using NPK fertilizer $300 \mathrm{~kg} \mathrm{ha}^{-1}$ and Urea $100 \mathrm{~kg}$ $\mathrm{ha}^{-1}$. Parameters observed included plant height $(\mathrm{cm})$, number of effective tillers (tillers), flag leaf length $(\mathrm{cm})$, panicle length $(\mathrm{cm})$, grain yield per plant $(\mathrm{g})$, and 1000 grains weight $(\mathrm{g})$. The data observed were all $\mathrm{F} 1$ and F1R plants without replication. Data were analyzed descriptively and tested using t-student's level $\alpha=5 \%$ using STAR 2.0.1 application.

\section{RESULTS AND DISCUSSION}

\subsection{Plant Height}

Based on Table 1, the crosses of the parents of the black rice paddy group which were crossed with the Inpari 13 variety and its reciprocal showed that the plant height was not significantly different for all cross combinations. The group of black rice crosses with Inpari 18 variety showed no significant difference between F1 and F1R except that the cross between PH4 $\times$ Inpari18 was significantly higher $(112.69 \mathrm{~cm})$ compared to F1R Inpari18 $\times$ PH4 around $93.25 \mathrm{~cm}$. This shows that there is a difference between female black rice parent that have a tendency of F1 derivatives to have a higher posture than Inpari 18 female parents. This is in line with the research of Nurhidayah and Umbara [12] that the height of the PH4 accession plant is around $137 \mathrm{~cm}$, and data from the Puslitbangtan [13] Inpari 18 variety has a height of about $93 \mathrm{~cm}$.

Table 1 The effect of cytoplasmic maternal in F1 and F1R on plant height

\begin{tabular}{|c|c|c|c|c|c|}
\hline No & Crossing & F1 & F1R & t-value & Prob $>|t|$ \\
\hline 1 & PH2×INPARI13 & 110.84 & 130.50 & -1.98 & 0.1417 \\
\hline 2 & PH3×INPARI13 & 120.62 & 124.67 & -0.77 & 0.4752 \\
\hline 3 & PH4×INPARI13 & 116.73 & 129.83 & -0.77 & 0.4755 \\
\hline 4 & PH5×INPARI13 & 112.21 & 124.67 & -1.03 & 0.3520 \\
\hline 5 & PH8×INPARI13 & 115.23 & 112.00 & 2.73 & 0.0718 \\
\hline 6 & PH3×INPARI18 & 105.67 & 108.25 & 1.56 & 0.2160 \\
\hline 7 & PH4×INPARI18 & 112.69 & 93.25 & 11.68* & 0.0013 \\
\hline 8 & PH5×INPARI18 & 107.80 & 96.83 & 1.72 & 0.1457 \\
\hline 9 & PH8×INPARI18 & 113.75 & 96.38 & 2.26 & 0.0586 \\
\hline 10 & PH2×INPARI19 & 124.20 & 117.00 & 0.67 & 0.5217 \\
\hline 11 & PH3×INPARI19 & 128.62 & 130.50 & -0.44 & 0.6719 \\
\hline 12 & PH5×INPARI19 & 113.56 & 122.50 & -1.26 & 0.2492 \\
\hline 13 & PH6×INPARI19 & 119.56 & 136.75 & $-3.9 *$ & 0.0300 \\
\hline 14 & PH7×INPARI19 & 125.20 & 124.40 & 0.57 & 0.5982 \\
\hline 15 & PH8×INPARI19 & 112.75 & 123.57 & 0.11 & 0.9156 \\
\hline
\end{tabular}

Notes: * significantly at 0.05 probability level

Meanwhile, black rice crosses with Inpari 19 showed the same majority as other crosses, namely there was no significant difference, except that F1 PH6 $\times$ Inpari19 was significantly shorter $(119.56 \mathrm{~cm})$ than F1R Inpari19 $\times$ PH6 $(136.75 \mathrm{~cm})$. In general, the combination of black rice accessions $\times$ Inpari 19 and its reciprocal tended to be the same and did not show any maternal effects unless the PH6 $\times$ Inpari 19 cross had a maternal effect. It is inversely proportional to the crossing of Inpari $18 \times \mathrm{PH} 4$ with Inpari19 $\times \mathrm{PH} 6$, where the Inpari 18 female parent has an F1 derivative following the female parent with a short posture, while the Inpari 19 female parent shows a taller plant.

\subsection{Flag Leaf Length}

Based on Table 2, as many as four cross combinations of black rice $\times$ Inpari 13 were not significantly different from F1R Inpari13 $\times$ black rice accessions. Only the F1 derivative PH5 $\times$ Inpari13 has a 
flag leaf longer than F1R Inpari13 $\times$ PH5. In the group of crosses of F1 PH3 $\times$ Inpari18, three combinations were significantly different. The F1 derivative $\mathrm{PH} 3 \times$ Inpari18 has significantly shorter flag leaves than the reciprocal. Meanwhile the F1R Inpari18 $\times$ PH4 and Inpari18 $\times$ PH5 derivatives had longer leaves when Inpari 18 became the female parent. In the study, all black rice accessions $\times$ Inpari19 had the same flag leaves or had no maternal effect. The results of research by Liu et al. [7], stated that the cytoplasmic effect affects the high and low content of rapeseed oil (Brassica napus) and the difference in oil content depends on each genotype.

Table 2. The effect of cytoplasmic maternal in F1 and F1R on flag leaf length

\begin{tabular}{|c|c|c|c|c|c|}
\hline No & Crossing & F1 & F1R & t-value & Prob $>|t|$ \\
\hline 1 & PH2×INPARI13 & 31.56 & 32.88 & 0.68 & 0.5167 \\
\hline 2 & PH3×INPARI13 & 26.19 & 31.38 & -1.33 & 0.2245 \\
\hline 3 & PH4×INPARI13 & 34.44 & 38.36 & -0.73 & 0.4813 \\
\hline 4 & PH5×INPARI13 & 38.44 & 30.00 & $5.12 *$ & 0.0006 \\
\hline 5 & PH8×INPARI13 & 33.75 & 39.50 & -1.38 & 0.2086 \\
\hline 6 & PH3×INPARI18 & 36.67 & 34.25 & $4.36 *$ & 0.0033 \\
\hline 7 & PH4×INPARI18 & 33.38 & 43.38 & $-2.71 *$ & 0.0301 \\
\hline 8 & PH5×INPARI18 & 30.79 & 37.36 & $-3.66^{*}$ & 0.0029 \\
\hline 9 & PH8×INPARI18 & 27.42 & 34.12 & -2.19 & 0.0507 \\
\hline 10 & PH2×INPARI19 & 40.67 & 40.59 & 0.63 & 0.5428 \\
\hline 11 & PH3×INPARI19 & 35.73 & 36.50 & -2.01 & 0.0728 \\
\hline 12 & PH5×INPARI19 & 40.58 & 42.00 & -1.25 & 0.2376 \\
\hline 13 & PH6×INPARI19 & 47.80 & 43.62 & 1.31 & 0.2307 \\
\hline 14 & PH7×INPARI19 & 34.00 & 36.36 & -0.58 & 0.5728 \\
\hline 15 & PH8×INPARI19 & 37.43 & 32.57 & 1.43 & 0.1755 \\
\hline
\end{tabular}

Notes: * significantly at 0.05 probability level

\subsection{Number of Effective Tillers}

According to Singh et al. [14], the number of effective tillers per plant is an important trait in rice crop that affects directly grain yield. Based on Table 3, there are two cross combinations that have different numbers of productive tillers, namely PH5 $\times$ Inpari13 and PH5 $\times$ Inpari19. Meanwhile, the other 13 crosses were not significantly different. The flag leaves became longer if the female parents used were Inpari13 and Inpari19 varieties, while PH5 female parents tended to have shorter leaves. Although statistically most of the crosses were not significantly different, in general the use of female parents of the Inpari13, Inpari18 and Inpari19 varieties which included white rice tended to have longer flag leaves.

Table 3. The effect of cytoplasmic maternal in F1 and F1R on number of effective tillers

\begin{tabular}{|c|c|c|c|c|c|}
\hline No & Crossing & F1 & F1R & t-value & Prob $>|t|$ \\
\hline 1 & PH2×INPARI13 & 7.67 & 11.75 & -2.78 & 0.0691 \\
\hline 2 & PH3×INPARI13 & 9.10 & 11.67 & -0.88 & 0.4202 \\
\hline 3 & PH4×INPARI13 & 8.12 & 11.83 & -2.12 & 0.0870 \\
\hline 4 & PH5×INPARI13 & 8.30 & 13.50 & $-12.25 *$ & 0.0012 \\
\hline 5 & PH8×INPARI13 & 10.29 & 9.75 & 1.61 & 0.2062 \\
\hline 6 & PH3×INPARI18 & 7.25 & 7.75 & 0.40 & 0.7177 \\
\hline 7 & PH4×INPARI18 & 7.12 & 5.25 & 1.89 & 0.1546 \\
\hline 8 & PH5×INPARI18 & 6.71 & 8.00 & -1.23 & 0.2722 \\
\hline 9 & PH8 $\times$ INPARI18 & 7.50 & 7.25 & 0.50 & 0.6355 \\
\hline 10 & PH2×INPARI19 & 6.83 & 8.83 & -0.98 & 0.3704 \\
\hline 11 & PH3×INPARI19 & 8.00 & 9.18 & -0.60 & 0.5737 \\
\hline 12 & PH5×INPARI19 & 5.86 & 8.12 & $-2.63^{*}$ & 0.0389 \\
\hline 13 & PH6×INPARI19 & 5.60 & 8.00 & -2.91 & 0.0622 \\
\hline 14 & PH7×INPARI19 & 6.50 & 9.00 & -2.67 & 0.0758 \\
\hline 15 & PH8×INPARI19 & 8.67 & 7.67 & 0.65 & 0.5430 \\
\hline
\end{tabular}




\subsection{Panicle Lenght}

The difference in panicle length is found in the F1 derivatives $\mathrm{PH} 3 \times$ Inpari13, $\mathrm{PH} 3 \times$ Inpari18, $\mathrm{PH} 4 \times$ Inpari18, PH5 $\times$ Inpari18, and PH7 $\times$ Inpari19. Inpari13 female parents had longer panicles $(25.5 \mathrm{~cm})$ than male parents $(21.81 \mathrm{~cm})$ at the $\mathrm{PH} 3 \times$ Inpari1 3 cross. Likewise, the crosses of PH5 $\times$ Inpari18 and PH7 $\times$ Inpari19, the female parents of white rice varieties had longer panicles than when they were made as male parents. On the other hand, the crosses PH3 PH $\times$ Inpari18 and PH4 $\times$ Inpari18

had short panicles when Inpari 18 was made the female parent. According to Munganyinka [15], reciprocal selection is a breeding procedure for population increase and hybrid development. Female and male parents contribute genes to their offspring, but the influence of the female parent often goes beyond simple genetic transmission. Genes in the cytoplasm play a modification in increasing resistance to RYMV disease. A cultivar carrying the RYMV resistant gene were better off as female parent than as a male parent.

Table 4. The effect of cytoplasmic maternal in F1 and F1R of panicle length

\begin{tabular}{|c|c|c|c|c|c|}
\hline No & Crossing & $\mathrm{F} 1$ & F1R & t-value & Prob $>|t|$ \\
\hline 1 & PH2×INPARI13 & 24.44 & 25.60 & -1.11 & 0.2971 \\
\hline 2 & PH3×INPARI13 & 21.81 & 25.50 & $-5.81 *$ & 0.0007 \\
\hline 3 & PH4×INPARI13 & 23.88 & 25.29 & -0.59 & 0.5627 \\
\hline 4 & PH5×INPARI13 & 23.12 & 24.50 & -1.37 & 0.2048 \\
\hline 5 & PH8 $\times$ INPARI13 & 24.00 & 24.88 & -0.64 & 0.5429 \\
\hline 6 & PH3×INPARI18 & 23.72 & 23.50 & $2.38 *$ & 0.0491 \\
\hline 7 & PH4×INPARI18 & 22.94 & 22.25 & $2.43 *$ & 0.0452 \\
\hline 8 & PH5×INPARI18 & 20.43 & 24.79 & $-5.90 *$ & 0.0001 \\
\hline 9 & PH8 $\times$ INPARI18 & 23.17 & 21.81 & 1.80 & 0.0987 \\
\hline 10 & PH2×INPARI19 & 25.83 & 30.23 & -1.84 & 0.0930 \\
\hline 11 & PH3×INPARI19 & 26.08 & 26.62 & -1.58 & 0.1416 \\
\hline 12 & PH5×INPARI19 & 25.17 & 26.75 & -1.69 & 0.1200 \\
\hline 13 & PH6×INPARI19 & 27.10 & 28.50 & -0.35 & 0.7363 \\
\hline 14 & PH7×INPARI19 & 24.00 & 26.73 & $-2.47 *$ & 0.0330 \\
\hline 15 & PH8×INPARI19 & 25.29 & 26.43 & -0.82 & 0.4258 \\
\hline
\end{tabular}

Notes: * significantly at 0.05 probability level

Tabel 5. The effect of cytoplasmic maternal in F1 and F1R on grain yield per plant

\begin{tabular}{|c|c|c|c|c|c|}
\hline No & Crossing & F1 & F1R & t-value & Prob $>|t|$ \\
\hline 1 & PH2×INPARI13 & 7.41 & 21.74 & -3.14 & 0.1965 \\
\hline 2 & PH3×INPARI13 & 10.01 & 28.52 & -8.39 & 0.0755 \\
\hline 3 & PH4×INPARI13 & 8.94 & 31.58 & -11.15 & 0.0569 \\
\hline 4 & PH5×INPARI13 & 15.71 & 33.91 & -2.81 & 0.218 \\
\hline 5 & PH8 $\times$ INPARI13 & 24.80 & 24.61 & 0.05 & 0.9673 \\
\hline 6 & PH3×INPARI18 & 24.16 & 24.55 & -0.06 & 0.9616 \\
\hline 7 & PH4×INPARI18 & 16.62 & 13.12 & 14.00 & 0.0454 \\
\hline 8 & PH5×INPARI18 & 8.11 & 23.43 & $-52.83 *$ & 0.012 \\
\hline 9 & PH8×INPARI18 & 6.88 & 21.20 & -8.28 & 0.0765 \\
\hline 10 & PH2×INPARI19 & 21.35 & 19.88 & 0.23 & 0.8571 \\
\hline 11 & PH3×INPARI19 & 26.00 & 30.83 & -0.72 & 0.6038 \\
\hline 12 & PH5×INPARI19 & 15.09 & 17.61 & -7.64 & 0.0829 \\
\hline 13 & PH6×INPARI19 & 13.82 & 27.8 & -9.61 & 0.066 \\
\hline 14 & PH7×INPARI19 & 6.51 & 22.95 & -1.62 & 0.3527 \\
\hline 15 & PH8 $\times$ INPARI19 & 17.33 & 24.5 & -0.89 & 0.5375 \\
\hline
\end{tabular}

\footnotetext{
Notes: * significantly at 0.05 probability level
} 


\subsection{Grain Yield Per Plant}

From all combinations of F1 and F1R crosses, it was seen that there was no maternal cytoplasmic effect unless there was 1 cross that was significantly different, namely the PH5 $\times$ Inpari 18 cross. Inpari 18 female parents had a higher weight per family (23.43 g) than when made male parents $(8.11 \mathrm{~g})$. In contrast to the research of Qin et al [11], the genes in the cytoplasm have a positive effect on yield and Tao et al. [16] cytoplasm has a significant effect on the grain weight of indica rice in two experimental locations from the three tested locations.

\subsection{Grain Weight}

Based on Table 6, from all combinations of $\mathrm{F} 1$ and F1R crosses, it can be seen that almost overall there are no cytoplasmic maternal effects except for 2 crosses that are significantly different, namely crosses $\mathrm{PH} 3 \times$ Inpari13 and PH4 $\times$ Inpari13. The use of Inpari 13 female parents weighs 1000 grains of $22.43 \mathrm{~g}$ while when they are male parents it is $17.73 \mathrm{~g}$ at the $\mathrm{PH} 4 \times$ Inpari13 cross. Meanwhile, from the PH4 $\times$ Inpari13 data, the Inpari 13 variety weight 1000 grains of $21.19 \mathrm{~g}$ when used as male parent and increases by $26.13 \mathrm{~g}$ when used as female parent.

Table 6. The effect of cytoplasmic maternal in F1 and F1R on the character of 1000 grain weight

\begin{tabular}{|c|c|c|c|c|c|}
\hline No & Crossing & F1 & F1R & t-value & Prob $>|t|$ \\
\hline 1 & PH2×INPARI13 & 24.07 & 21.10 & 1.23 & 0.34 \\
\hline 2 & PH3×INPARI13 & 17.73 & 22.43 & $-12.41 *$ & 0.01 \\
\hline 3 & PH4×INPARI13 & 21.90 & 26.13 & $-12.51 *$ & 0.01 \\
\hline 4 & PH5×INPARI13 & 22.47 & 22.83 & -0.62 & 0.60 \\
\hline 5 & PH8×INPARI13 & 23.53 & 22.03 & 0.56 & 0.63 \\
\hline 6 & PH3×INPARI18 & 26.00 & 24.97 & 0.75 & 0.53 \\
\hline 7 & PH4×INPARI18 & 25.17 & 26.50 & -1.04 & 0.41 \\
\hline 8 & PH5×INPARI18 & 21.97 & 22.33 & -0.14 & 0.90 \\
\hline 9 & PH8×INPARI18 & 19.03 & 24.97 & -2.63 & 0.12 \\
\hline 10 & PH2×INPARI19 & 22.67 & 22.67 & 0.00 & 1.00 \\
\hline 11 & PH3×INPARI19 & 22.20 & 21.87 & 0.32 & 0.78 \\
\hline 12 & PH5×INPARI19 & 24.93 & 23.37 & 0.88 & 0.47 \\
\hline 13 & PH6×INPARI19 & 25.77 & 29.10 & -2.05 & 0.18 \\
\hline 14 & PH7×INPARI19 & 22.40 & 22.53 & -0.18 & 0.87 \\
\hline 15 & PH8 $\times$ INPARI19 & 23.93 & 24.47 & -0.28 & 0.80 \\
\hline
\end{tabular}

Notes: * significantly at 0.05 probability level

\section{CONCLUSION}

In several crosses the maternal effect was found for plant height, flag leaf length, number of effective tillers, panicle length, weight per plant and weight of 1000 grains. According to the result of maternal effects on 1000 grain weight and grain yield, PH3, PH4, and PH5 cultivars are recommended to be used as the male parents to improve the performance of the filial generations.

\section{ACKNOWLEDGMENT}

This work was supported by Directorate of Research and Community Service, Ministry of Research and Technology/National Agency for Research and Innovation through competitive grants for Research Collaboration between Universities for the 2020 budget year between Universitas Perjuangan Tasikmalaya and Universitas Jenderal Soedirman.

\section{REFERENCES}

[1] Badan Pusat Statistik/Central Bureau of Statistics Statistics Indonesia, 'Statistical year book of Indonesia 2020', BPS, Indonesia, 2020.

[2] BPS-Statistics Indonesia, 'Kajian konsumsi bahan pokok tahun 2017', BPS, Indonesia, 2017.

[3] D.Y. Rafii, M.Z. Zakiah, R. Asfaliza, M.D. Iffah Haifaa, M.A. Latif, and M.A. Malek, 'Grain quality performance and heritability estimation in selected F1 rice genotypes', Sains Malaysiana, vol. 43, no. 1, pp. 1-7, 2014.

[4] BPS-Statistics Indonesia, 'Luas panen, produksi, dan produktivitas padi menurut provinsi 20182019', Accessed: Sept. 20, 2020. [Online]. Available: https://www.bps.go.id.

[5] BPS-Statistics Indonesia, 'Impor beras menurut negara asal utama 2000-2019', Accessed: Sept. 20, 2020. [Online]. Available: https://www.bps.go.id. 
[6] Sumaryanto, S. Friyatno, and B. Irawan, 'Paddy field conversion to non-agriculture utilization and its negative impacts'. Prosiding Seminar Nasional Multifungsi Lahan Sawah, Indonesia, pp. 1-18, 2017.

[7] J. Liu, W. Hao, J. Liu, S. Fan, W. Zhao, L. Deng, X. Wang, Z. Hu, W. Hua, and H. Wang, 'A novel chimeric mitochondrial gene confers cytoplasmic effects on seed oil content in polyploid rapeseed (Brassica napus)', Cell Press Partner Journal, vol. 12, no. 1, pp. 582-596, 2019.

[8] A.S. Waja, and K.H. Jaiswal, 'Effects of WA cytoplasm on various quality characteristics of rice hybrids', The Journal of Animal and Plant Sciences, vol. 25, no. 6, pp. 1693-1698, 2015.

[9] R.M. Zangi, B.N. Jelodar, K.S. Kazemitabar, and M. Vafaei-tabar, 'Cytoplasmic and combining ability effects on agro-morphological characters in intra and inter crosses of Pima and upland cottons (G. hirsutum and G. barbadense)', International Journal of Biology. vol. 2 no. 1, pp. 94-102, 2010.

[10] S. El-Bok, F. Bnejdi, and M. El-Gazzah, 'Evidence of cytoplasmic and epistatic effects in inheritance of grain protein content in durum wheat', WFL Publisher Science and Technology, vol. 11, no. 3 and 4, pp. 804-806, 2013.

[11] P. Qin, Y. Wang, Y. Li, B. Ma, and S. Li. 'Analysis of cytoplasmic effects and fine-mapping of a genic male sterile line in rice', Plos One. vol. 8, no. 4, pp. 1-9, 2013.

[12] S. Nurhidayah, and D.S. Umbara, 'Perbedaan komponen vegetatif dan generatif pada lima aksesi padi hitam (Oryza sativa L.) di kecamatan indihiang tasikmalaya jawa barat', Agriprima, Journal of Applied Agricultural Sciences, vol. 3, no. 1, pp. 16-22, 2019.

[13] Pusat Penelitian dan Pengembangan Tanaman, 'Deskripsi varietas unggul tanaman pangan 20102016', Pusat Penelitian dan Pengembangan Tanaman. Indonesia, 2016.

[14] M.Kr. Singh, R.P. Singh, P. Singh, R.Kr. Singh, and R.P. Srivastava, 'Reciprocal crosses in early maturing $\mathrm{x}$ high yielding rice (Oryza sativa L.) cultivars', Journal of Pharmacognosy and Phytochemistry. Vol. 5, pp. 50-55, 2018.

[15] E. Munganyinka, R. Edema, J. Lamo, P. Gibson, and D. Gahakwa, 'Maternal genetic effect of resistance to rice yellow mottle virus disease in rice', International Journal of Agronomy and Agricultural Research (IJAAR), vol. 6, no. 4, pp. 213-221, 2015

[16] D. Tao, P. Xu, J. Zhou, X. Deng, J. Li, W. Deng, J. Yang, G. Yang, Q. Li, F. Hu, Cytoplasm affects grain weight and filled-grain ratio in indica rice, BMC Genetics, vol. 12, no. 53, pp. 1-6, 2011. 